\title{
Corrosion Behavior of TIG Welded AlMg6Mn Alloy
}

\author{
Ljubica Radović ${ }^{1)}$ \\ Mihail Bučko ${ }^{2)}$ \\ Marko Miladinov ${ }^{2)}$
}

\begin{abstract}
The influence of TIG welding on the corrosion and mechanical properties of AIMg6Mn was investigated. The as-received hot rolled AIMg6Mn alloy plates (AR) with a thickness of $8 \mathrm{~mm}$ were welded by TIG welding with S-AIMg5 as a filler material. The microstructure, mechanical properties and corrosion behavior of the weld joint filled with AlMg5 welding wires, were studied by optical microscopy, scanning electron microscopy, hardness testing and corrosion NAMLT and ASSET tests. It was found that AR is more susceptible to intergranular corrosion than TIG welding specimens, while neither AR nor TIG specimens showed susceptibility to exfoliation corrosion
\end{abstract}

Key words: alloys, Al-Mg-Mn alloys, welding, TIG welding, welded joint, corrosion, intergranular corrosion, mechanical properties.

\section{Introduction}

$\mathrm{M}$ EDIUM strength highly formable 5xxx Al-Mg alloys have been widely used, especially for structural applications, in the constructions of transportation due to different combination of strength and formability [1-4]. Such properties can be achieved by the mechanism of solid solution hardening, and enhanced by deformation due to the high strain hardening behavior [5]. Further improvements in properties, such as good weldability and high corrosion resistance, have been achieved by small additions of other alloy elements and/or modified processing routes ${ }^{[6-9]}$.

Despite that, as concerning one of the mostly used commercial $\mathrm{Al}-\mathrm{Mg}$ alloys, EN AW-5083 (Al-4.7Mg-0.7Mn), the further increase in its magnesium content has recently been in the focus of interest [10-13]. Alloy with 6 wt. \% of Mg possesses a good weldability and a good combination of strength and formability $[11,1214]$. However, the increase of the $\mathrm{Mg}$ content, as well as the presence of different kind of intermetallic phases in the alloy, increases the strength, but leads to a higher susceptibility to the localized corrosion [3]. Al-Mg alloys with more than $3 \% \mathrm{Mg}$, due to the limited room temperature solubility of $\mathrm{Mg}$ in $\mathrm{Al}$ matrix (1.9 wt. \% Mg), become supersaturated and the excess $\mathrm{Mg}$ atoms precipitate out as anodic $\beta-\mathrm{Al}_{3} \mathrm{Mg}_{2}$ phase. Because of the low melting points of these alloys substantial diffusion of $\mathrm{Mg}$ occurs at the temperatures approaching room temperature, $\beta$-phase precipitates preferentially at both grain boundaries and on preexisting particles which are enriched in manganese [15-17]. It is considered that the grain boundaries are preferential site for $\beta$ phase nucleation due to the low diffusion barrier (presence of defects, such as dislocations and vacancies) [18]. Under certain conditions, either during the fabrication of the sheet plate $\mathrm{Al}-\mathrm{Mg}$ products or in service, extended exposure in the range $70^{\circ} \mathrm{C}$ to $200^{\circ} \mathrm{C}$, can cause the precipitation of Mg-rich $\beta$-phase, preferentially at the grain boundaries. It makes these alloys become „sensitized", susceptible to intergranular (IGC), stress (SCC), or pitting corrosion since, the $\beta$-phase is electrochemically more active than the aluminum matrix [19-22] .

A specific form of IGC, often encountered in $\mathrm{Al}$ alloys, is exfoliation corrosion, characterized by lifting up of the metal surface by force of expanding corrosion products occurring at the grain boundaries [23]. Exfoliation corrosion occurs when the grains are flattened by a heavy deformation during hot or cold rolling, and where no recrystallization has occurred [19].

In the environments where $\mathrm{Al}$ alloys are susceptible to IGC, a discrete pitting or pit blistering is to be expected also, i.e. the formation of small holes along the surface.

Despite that. most of the works examine the effect of sensitisation and influence of $\beta$-phase on the localized corrosion, the other intermetallics also play an important role in the localized corrosion attack $\left((\mathrm{Fe}, \mathrm{Mn}) \mathrm{Al}_{6}, \mathrm{Mg}_{2} \mathrm{Si}, \mathrm{Al} \mathrm{Mn}\right.$, $\mathrm{Al}_{3} \mathrm{Mg}_{5}$ ). The influence of intermetallic particles on the resistance against localized corrosion is crucial for the material integrity in long-term service, but data of corrosion resistance of this alloy are lacking.

Tungsten inert gas (TIG) welding is one of the most common joining methods for aluminum alloys. During the welding process, the phase transformation and softening phenomena are induced due to the heat, providing differences in microstructure, mechanical properties as well as electrochemical potential difference between various zones of the weld. Many authors found that the corrosion resistance of the welded materials at different regions that formed during the welding process is not the same [24-26].

Nitric Acid Mass Loss Testing (NAMLT) [27], is the most common method for evaluating the susceptibility of Al-Mg alloys to IGC, since it provides a quantitative measure of susceptibility. There are numerous studies that have investigated the effects of welding on the IGC of Al-Mg alloys containing up to $5 \% \mathrm{Mg}[17,18]$. However, there is a

\footnotetext{
1) Military Technical Institute (VTI), Ratka Resanovića 1, 11132 Belgrade, SERBIA

2) University of Defense, Military Academy, Pavla Jurišića Šturma 33, 11000 Belgrade, SERBIA

Correspondence to: LJubica Radović; e-mail: ljubica.radović@vti.vs.rs
} 
lack of evidence documenting the corrosion behavior of AlMg6Mn alloy.

The aim of this work was the evaluation of the corrosion resistance of hot rolled aluminum alloy AlMg6Mn, and TIG welded joints of the same alloy.

\section{Experimental}

\section{Material}

The material used in this study was received as a hot rolled plate of AlMg6Mn alloy, $8 \mathrm{~mm}$ thickness in as-received condition (AR). The chemical composition of the used parent alloy is given in Table 1 . The $50 \mathrm{~mm}$ dimension was parallel to the longitudinal direction of the product (L-S).

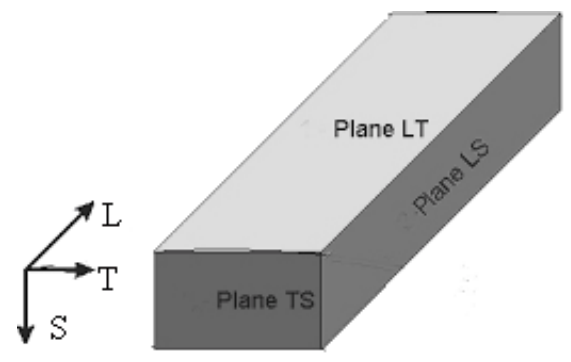

Figure 1. The deformation direction with respect to rolling direction of the plate: L-longitudinal (rolling direction); T- transversal; S-short transversal.

Table 1. Chemical composition of the AlMg6Mn alloy (wt. \%)

\begin{tabular}{|c|c|c|c|c|c|c|c|c|}
\hline $\mathrm{Mg}$ & $\mathrm{Si}$ & $\mathrm{Cu}$ & $\mathrm{Mn}$ & $\mathrm{Fe}$ & $\mathrm{Zn}$ & $\mathrm{Ni}$ & $\mathrm{Ti}$ & $\mathrm{Al}$ \\
\hline \hline 5.95 & 0.12 & 0.015 & 0.54 & 0.36 & 0.07 & 0.01 & 0.01 & Bal. \\
\hline
\end{tabular}

Welding

Specimens were welded using the TIG process under Ar (99.5\%) atmosphere and $\mathrm{S}-\mathrm{AlMg} 5$ as a filler material, using following welding parameters: current of $115 \mathrm{~A}$, voltage of 15 $\mathrm{V}$, and speed of $100 \mathrm{~mm} / \mathrm{min}$. The chemical composition of the filler material is given in Table 2. Direction of the welding joint was perpendicular to the plate rolling direction.

Table 2. Chemical composition of the filler material, S-AlMg5 (wt. \%)

\begin{tabular}{|c|c|c|c|c|c|c|c|c|}
\hline $\mathrm{Mg}$ & $\mathrm{Si}$ & $\mathrm{Cu}$ & $\mathrm{Mn}$ & $\mathrm{Fe}$ & $\mathrm{Zn}$ & $\mathrm{Ti}$ & $\mathrm{Cr}$ & $\mathrm{Al}$ \\
\hline \hline $4.5-5.5$ & $\begin{array}{c}\max \\
0.25\end{array}$ & 0.1 & $0.05-0.2$ & $\max 0.4$ & $\max 0.1$ & $0.06-0.2$ & $0.05-0.2$ & Bal. \\
\hline
\end{tabular}

\section{Microstructure}

The microstructures were characterized by the Leitz optical microscope (OM) and scanning electron microscope (SEMJEOL JSM-6610LV). Metallographic samples were prepared using traditional grinding and polishing techniques using up to $1 \mu \mathrm{m}$ diamond paste. The particle structure was evaluated in the polished samples. To reveal the grain structure, after the electrolytic polishing in perchloric acid, the samples were etched in the Barker's solution.

\section{Hardness}

The Vickers hardness distribution of the weld zone was measured on a cross section perpendicular to the welding direction using micro hardness tester with load of 4.9 N.

\section{Corrosion tests}

The corrosion resistance tests were performed on specimens containing the weld in the central zone and on the parent alloy. Tests were carried out by means of susceptibility to intergranular and exfoliation corrosion.

The susceptibility to IGC was determined by the nitric acid mass loss test (NAMLT) according to the ASTM G67 standard. Specimens, with dimensions $50 \times 6 \mathrm{~mm}$ and the thickness of the hot rolled plate of $8 \mathrm{~mm}$, were immersed in concentrated $\mathrm{HNO}_{3}$ at $30^{\circ} \mathrm{C}$ for 24 hours, and the mass loss was measured. The $50 \mathrm{~mm}$ dimension of the specimens was parallel to the longitudinal direction of the plate (rolling direction). Three specimens were tested. In order to calculate the mass losses per unit area more precisely, face and root reinforcement was considered.

The susceptibility to exfoliation corrosion was determined by a visual inspection using the ASSET method according to the ASTM G66 standard (Method for Visual Assessment of Exfoliation Corrosion susceptibility of AA5xxx Series Al alloys).

\section{Results and discussion}

\section{Microstructure}

Microstructure of the parent metal and weld joint before the corrosion tests is shown in Figures 2-4. All micrographs were taken on the $\mathrm{L}-\mathrm{S}$ plane. The micrograph of a grain structure of the parent metal (Fig.2(a)) shows the elongated grains after hot rolling. The particles are aligned in the rolling direction (Fig.2(b)).

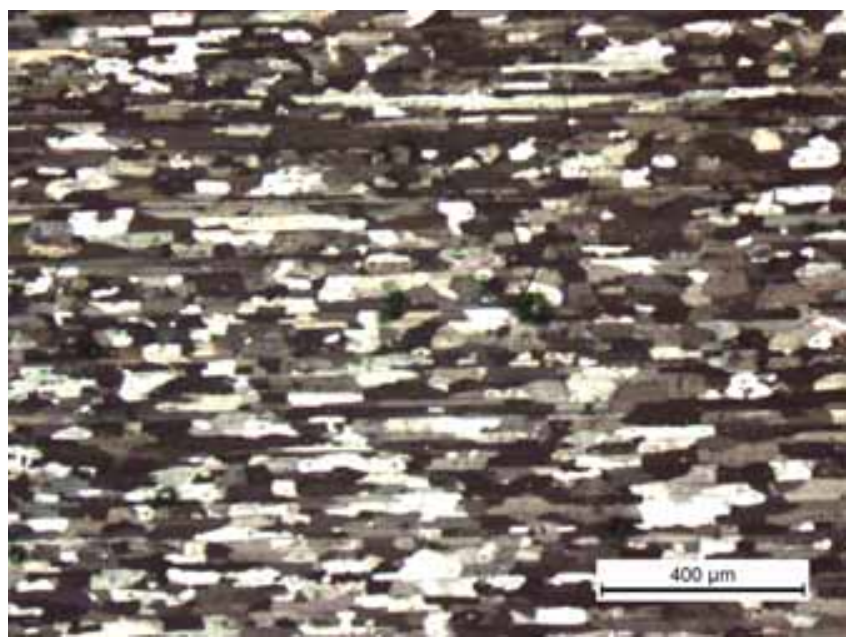

a)

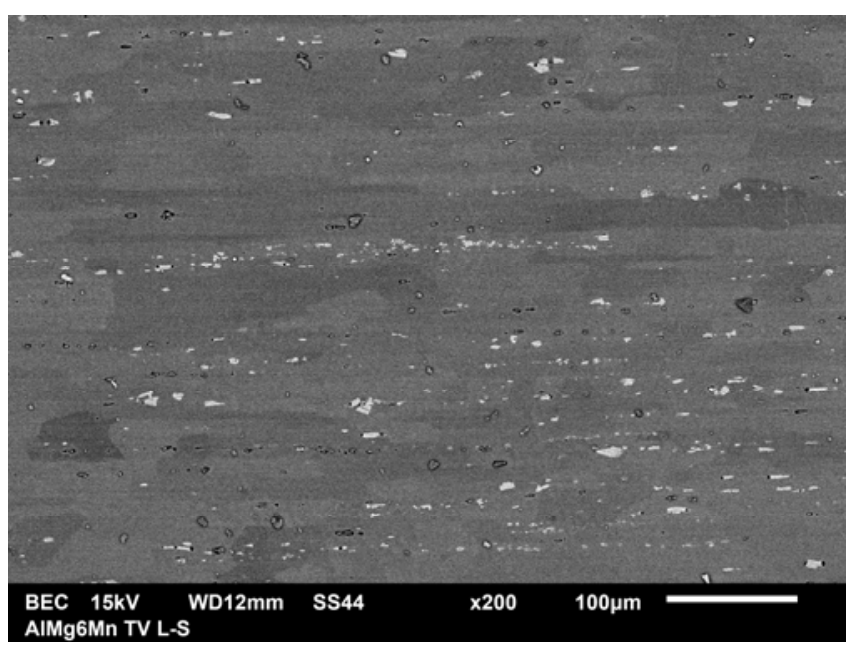

b)

Figure 2. Microstructure of the base metal (L-S plane): a) Grain structure (OM); b) Particle structure (SEM). 
The grains in the weld metal (WM) are equiaxed (Fig.3a) with a low content of homogenous distributed small particles (Fig.4a). The fusion zone (FZ) is clearly noticeable (Fig.3b). Some porosity is observed in the weld metal and in the vicinity of the fusion zone (as pointed out by arrows in Figs.4a and b). The heat affected zone (HAZ) is narrow with slightly elongated, recrystalized grains (Fig.3c) and precipitation of the second phase particles at the grain boundaries were observed (Fig.4c).



a)

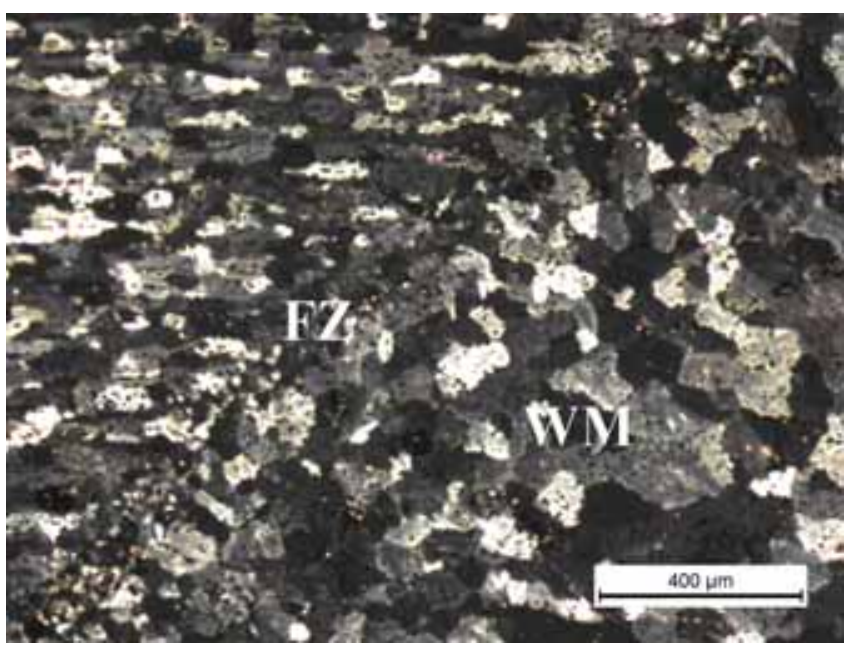

b)

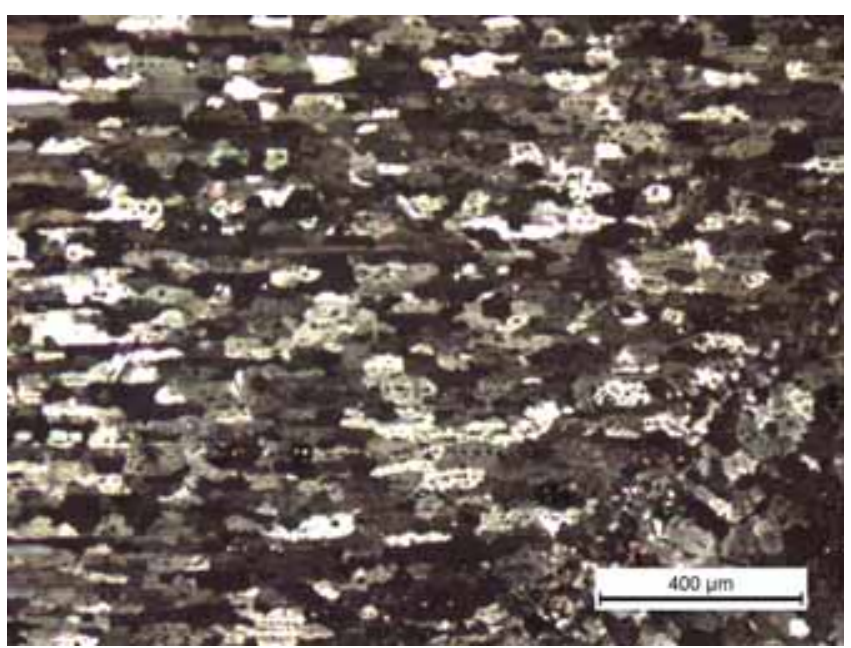

c)

Figure 3. Microstructure of the TIG welded joint: a) WM; b) FZ; c) HAZ;

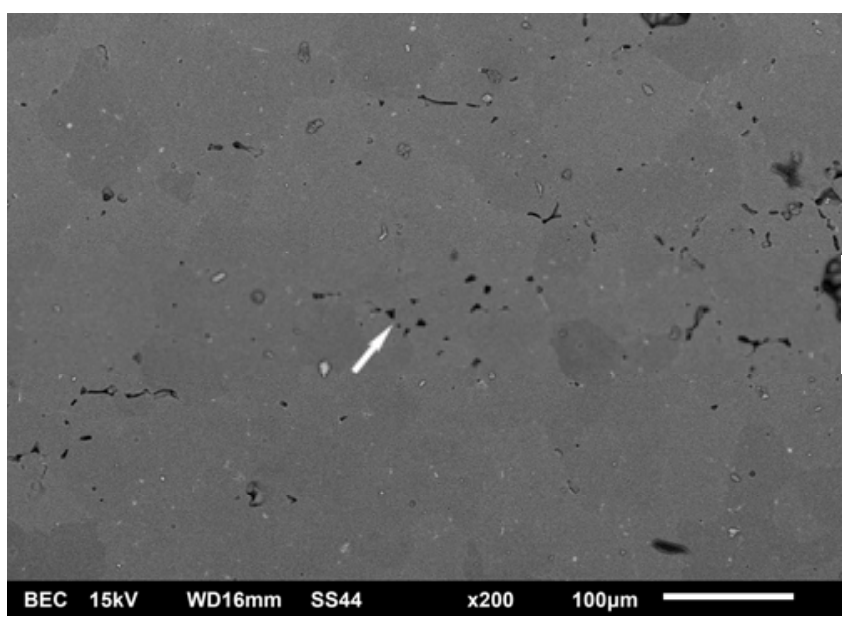

a)

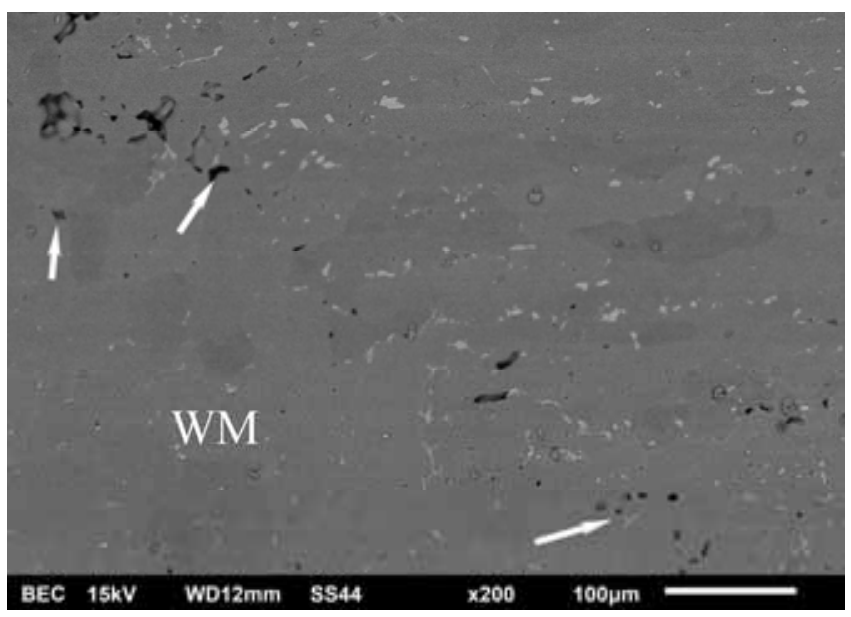

b)

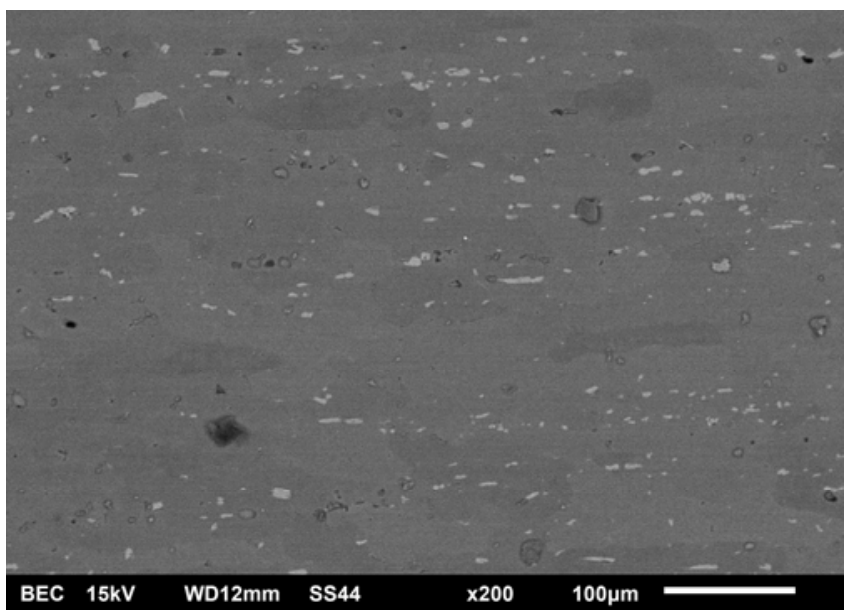

c)

Figure 4. Particle distribution in the TIG welded joint a) WM; b) FZ; c) HAZ.

\section{Hardness}

Hardness distribution along the weld joint is shown in Fig.5. The hardness of the base metal was approximately 90 $\mathrm{HV}_{0.5}$, while the weld metal zone has the lowest hardness value, $80-85 \mathrm{HV}_{0.5}$. This is the result of a dendritic microstructure occurred by the solidification of a molten filler material (AlMg5), coarser grain size, some porosity, as well as lower content of the second phase particles compared to the AlMg6Mn alloy. 




Figure 5. Hardness distribution across the weld joint.

\section{Corrosion properties}

The effect of TIG welding on the IGC susceptibility of the tested alloy was carried out by means of the NAMLT corrosion testing. Samples of the parent material, as well as of the welded plates before and after the corrosion test, are shown in Figures 6 and 7. It is clear that the surface of both the base metal and weld joint is rougher after the $24 \mathrm{~h}$ exposure to $\mathrm{HNO}_{3}$. However, it is interesting that more intensive attack was observed in the base metal (Fig.6b) than in the base metal of the welded specimens (Fig.7b).

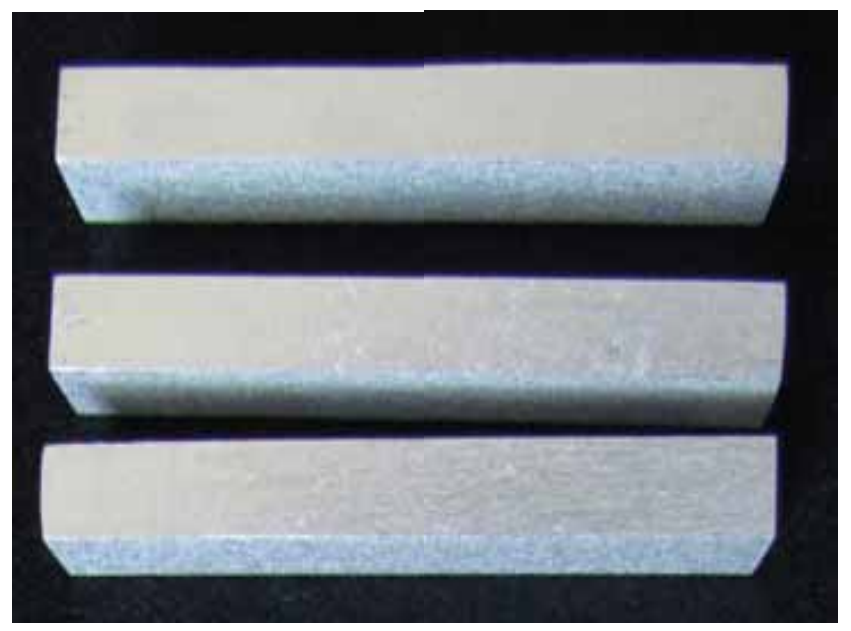

a)

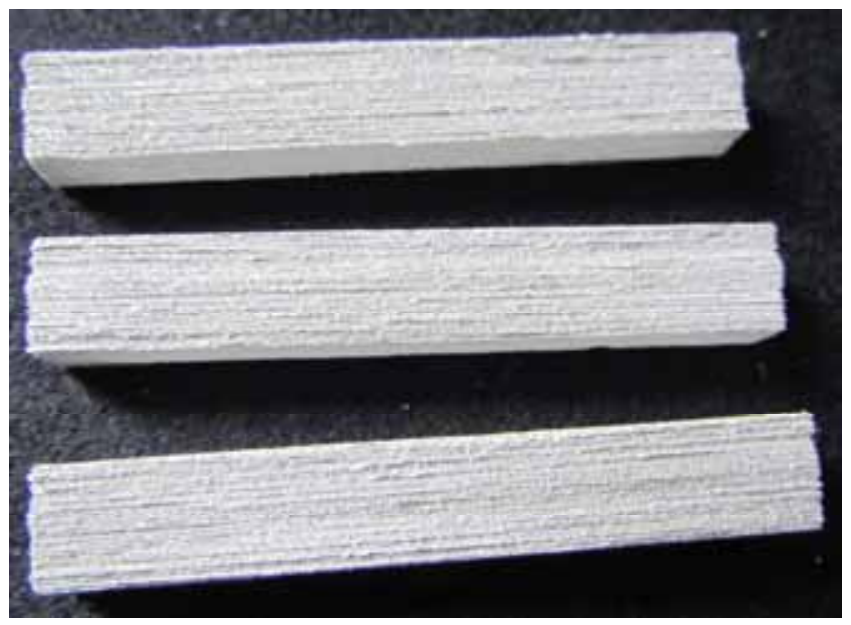

b)

Figure 6. Specimens of AlMg6Mn alloy (AR) before (a) and after (b) the NAMLT test.

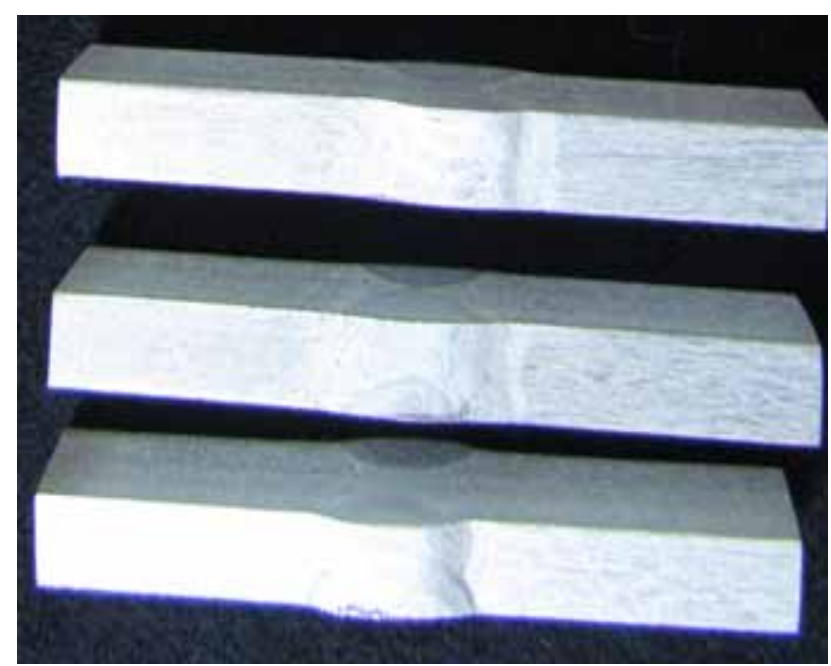

a)

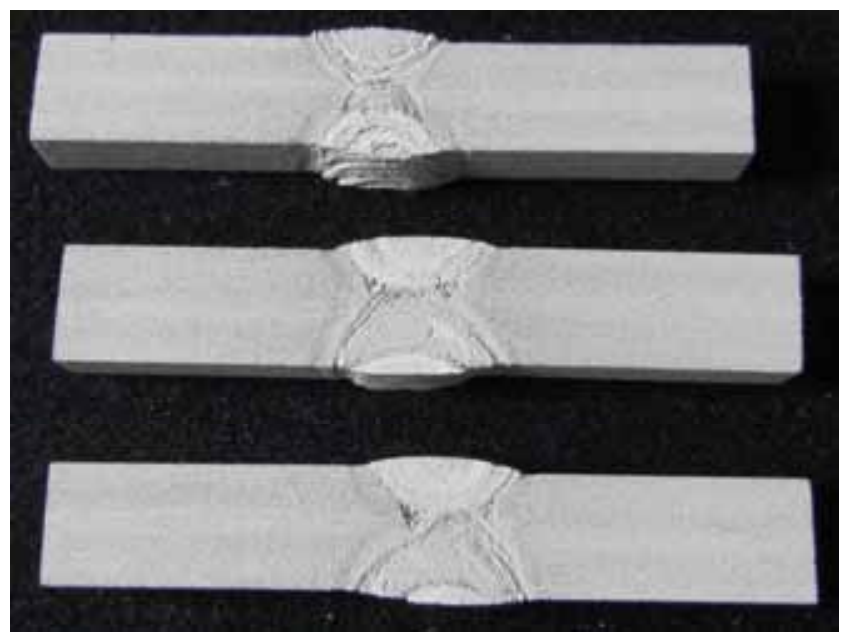

b)

Figure 7. TIG welded specimen of AlMg6 alloy before (a) and after (b) the NAMLT test.

The mass loss of the specimens with and without the weld joint is presented in Table 3 . It was found that the mass loss in the base material specimens was much higher (aver. $89.4 \mathrm{mg}$ $\mathrm{cm}^{-2}$ ), compared to the TIG welding processed specimens (15.45 to $30.48 \mathrm{mg} \mathrm{cm}^{-2}$ ). It shows that the IGC susceptibility was strongly affected by TIG process, i.e. the welded specimens showed higher resistance toward IGC. According to ASTM G67, a large mass loss $\left(>75 \mathrm{mg} \mathrm{cm}^{-2}\right)$ can be related to distribution of the $\beta$-phase in a continuous network along the grain boundaries [27]. The mass loss measured for the welded specimens is considered according to ASTM G67 as an intermediate value. This indicates the lower content or/and random distribution of the $\beta$-phase particles and both of them decrease the IGC susceptibility. The lower content of $\mathrm{Mg}$ in a weld metal compared to base metal, as well as fast cooling during solidification of the weld metal, result the lower content of the $\beta$-phase, since the $\beta$-phase precipitates below $200^{\circ} \mathrm{C}$ and with a slow growth rate [18]. Unlike samples of the parent metal where the mass loss was almost equal among all three samples, the mass loss among TIG samples varies. It is supposed that this is the result of different amount of porosity and gas bubbles in the weld zones, which causes slightly different intensity of the corrosion attack. In support of the statements a different morphology is also observed after the corrosion test (Fig. 7b). 
Table 3. Metal loss in NAMLT test

\begin{tabular}{|c|c|c|c|c|c|}
\hline $\begin{array}{l}\text { Specimen } \\
\text { type }\end{array}$ & Area $\left(\mathrm{cm}^{2}\right)$ & $\begin{array}{l}\text { Mass before } \\
\text { NAMLT test } \\
(\mathrm{mg})\end{array}$ & $\begin{array}{l}\text { Mass after } \\
\text { NAMLT test } \\
(\mathrm{mg})\end{array}$ & \multicolumn{2}{|c|}{$\begin{array}{l}\text { Mass loss } \\
\left(\mathrm{mg} / \mathrm{cm}^{2}\right)\end{array}$} \\
\hline \multirow{3}{*}{$\mathrm{AR}$} & 14.42 & $\bar{~} 5.9160$ & 4.6277 & 89.34 & \multirow{3}{*}{$\begin{array}{c}\text { Aver. } \\
89.4\end{array}$} \\
\hline & 14.43 & 5.9345 & 4.6645 & 88.07 & \\
\hline & 14.44 & 5.9231 & 4.6111 & 90.98 & \\
\hline \multirow{3}{*}{ TIG } & 14.55 & 6.1180 & 5.8395 & \multicolumn{2}{|c|}{19.14} \\
\hline & 14.63 & 6.1411 & 5.6951 & \multicolumn{2}{|c|}{30.48} \\
\hline & 14.61 & 5.9843 & 5.7585 & \multicolumn{2}{|c|}{15.45} \\
\hline
\end{tabular}

\section{Surface morphology after NAMLT test}

Figures 8a and $8 \mathrm{~b}$ show typical surface of base metal after the NAMLT test. Severe dissolution along the grain boundaries is observed in both L-S and L-T plains. It can be assumed that pits were initiated at anodic $\beta$-phase particles, which is preferentially dissolved and then grown along the grain boundaries, supported by other pits or dissolved matrix (model proposed by ref. 31), the presence of $\mathrm{Mg} 2^{+}$ions in solution increases the rate of dissolution of aluminum).

Numerous small pits on the grain surface are observed (Fig.8b). It is supposed that those pits are caused by dissolution of $\beta$-phase particles. This could be checked by revealing the distribution of the $\beta$-phase in the microstructure.

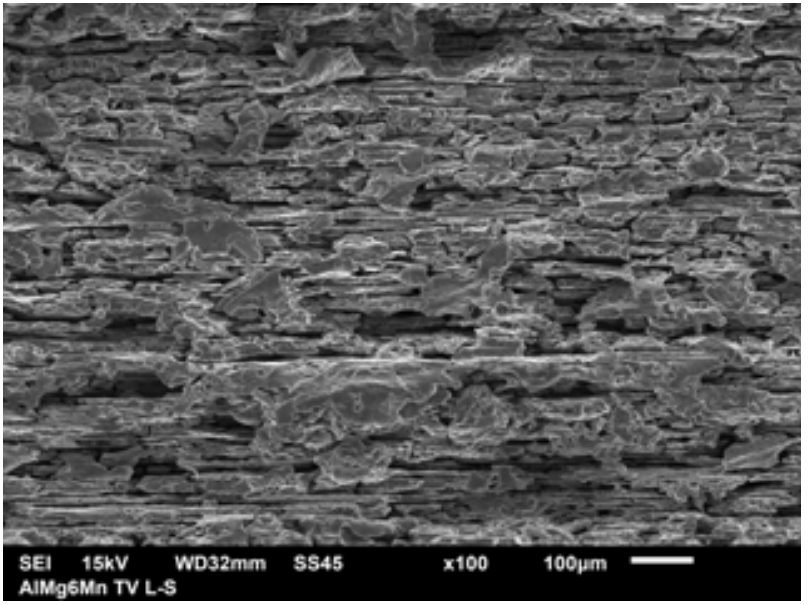

a)

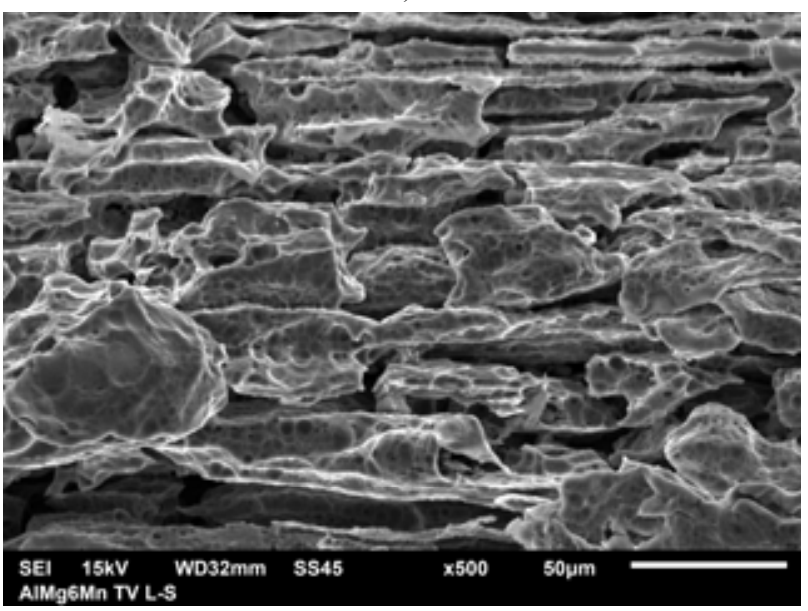

b)

Figure 8. Surface morphology of AR specimen after NAMLT test, in L-S plane, at different magnification: a) 100x; b) 500x.

The typical morphology of the TIG welded joint surface after NAMLT is shown in Fig.9. It can be noted that the surfaces of all zones, even the base metal, are covered with dimples. Unlike the AR specimens (Fig.8), in any of the welded joint zones intergranular attack was not observed, which was confirmed by the analysis at higher magnification (Fig.10).

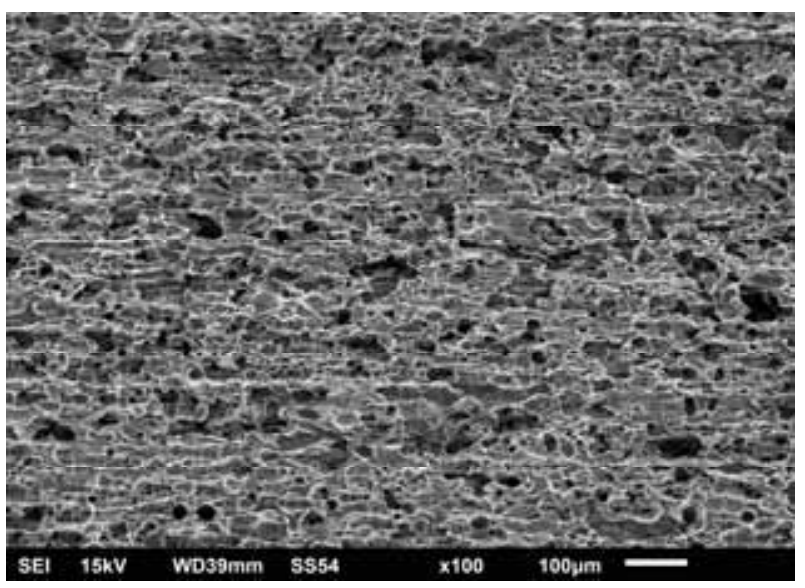

a)

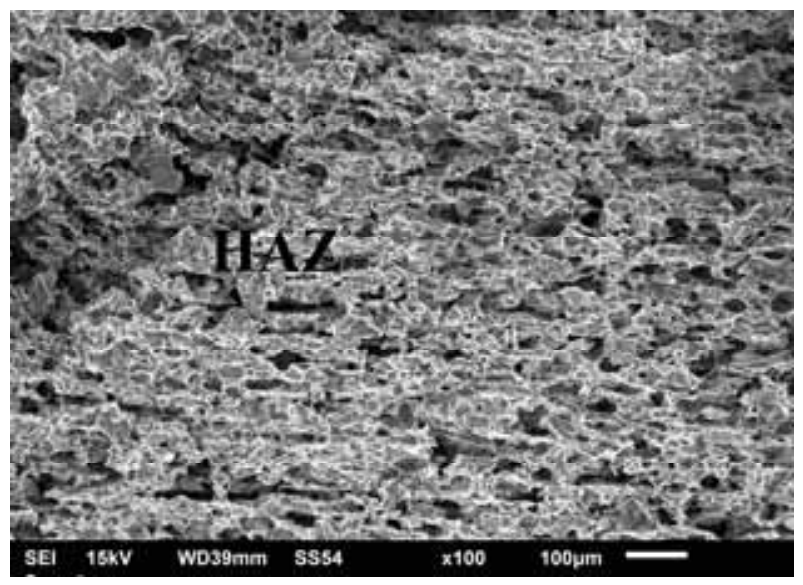

b)

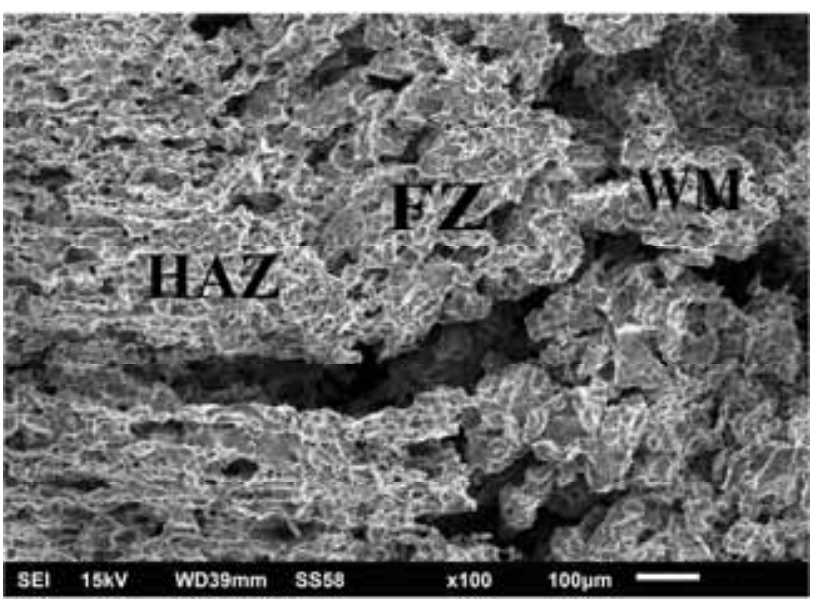

c)

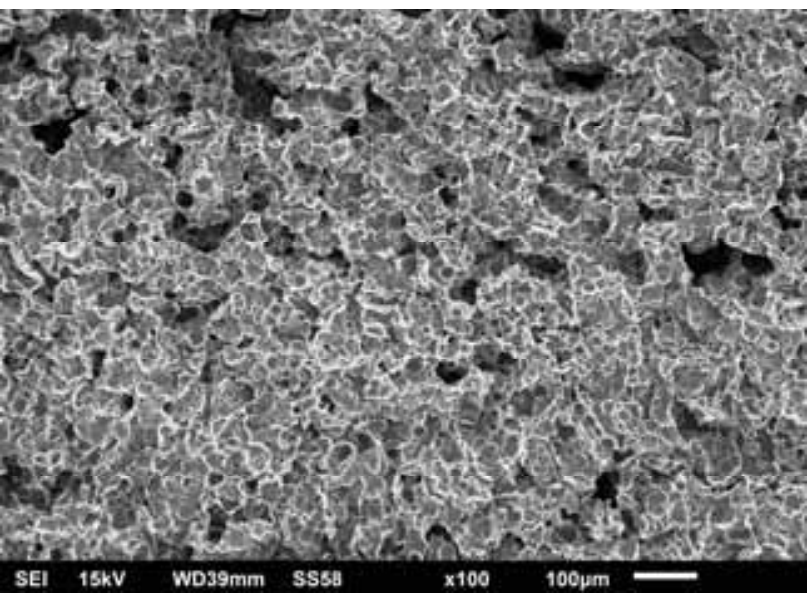

d)

Figure 9. Surface morphology of the weld joint after the NAMLT test: a) base metal; b) HAZ; c) FZ; d) WM. 
Such difference in the surface morphology between the AR and TIG specimens after corrosion test is a little unexpected, and requires further investigation, special distribution of the $\beta$-phase, since the preferential attack of approximately continuous $\beta$-phase particles at the grain boundaries is believed to be responsible for IGC [19].

Large pores, mostly in the fusion zone and weld metal, were observed (Figs.9c, d). Comparing these pore size with the pores size in Fig.4, it seems that pores are preferential sites for corrosion attack. However, the mass loss in the TIG specimens was lower than in AR specimens (Table 3). Since the mass loss in the TIG welded specimens is a sum of both, mass loss in the weld metal, HAZ and base metal, on the base of the previous results it has not been possible to calculate the fraction of each of them. But, according to the surface morphology after the NAMLT test, corrosion of the base metal of TIG specimens is less intensive than in AR specimens.

While severe corrosion attack along the grain boundary was observed in AR specimens (Fig. 8), in the base metal of TIG specimens an intergranular attack was not observed (Fig.9). It can be attributed to different microstructure of the weld metal zone (primarily lower content of the $\beta$-phase, and lower content of Mn-bearing phases), but it should be investigated thoroughly.

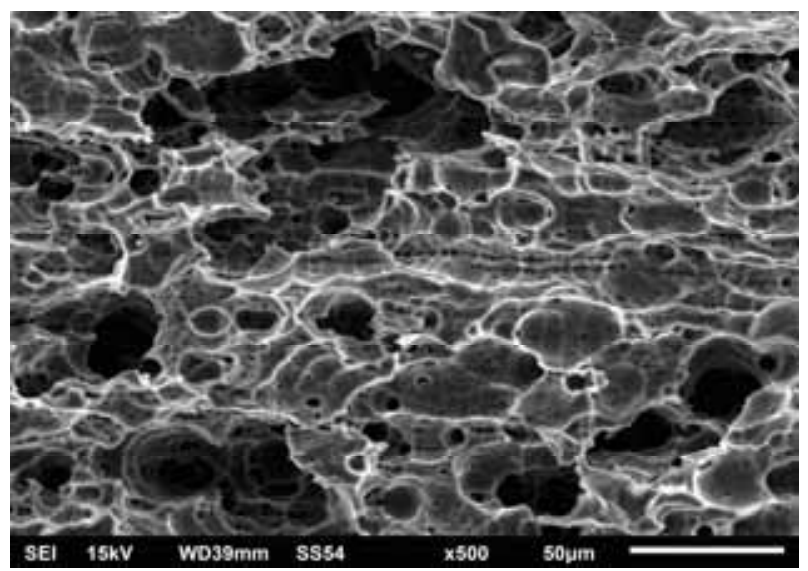

a)

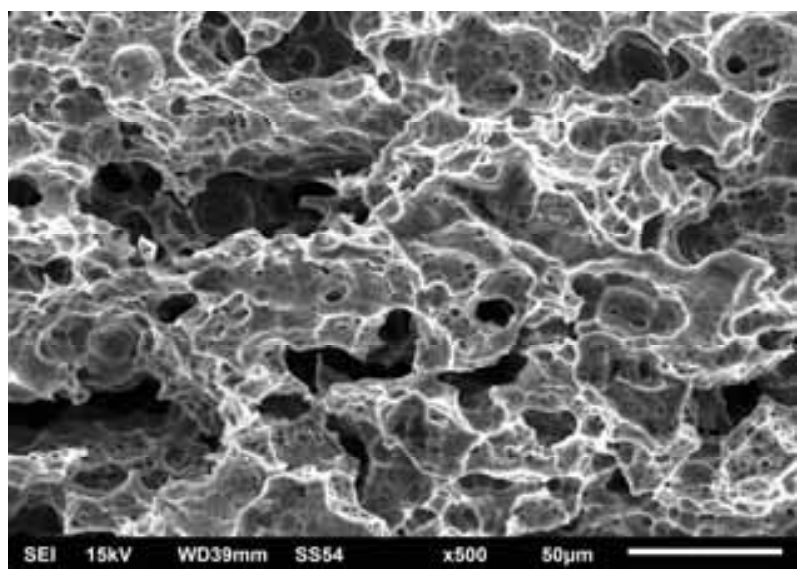

b)

\section{Conclusion}

The susceptibility to intergranular (IGC) and exfoliation corrosion of TIG welded and as-received specimens of AlMg6Mn alloy were investigated according to the ASTM G67 and ASTM G66 standards. As-received AlMg6Mn alloy has shown susceptibility to IGC, as the mass loss determined by NAMLT test was $89,4 \mathrm{mg} / \mathrm{mm}^{2}$. The TIG welded

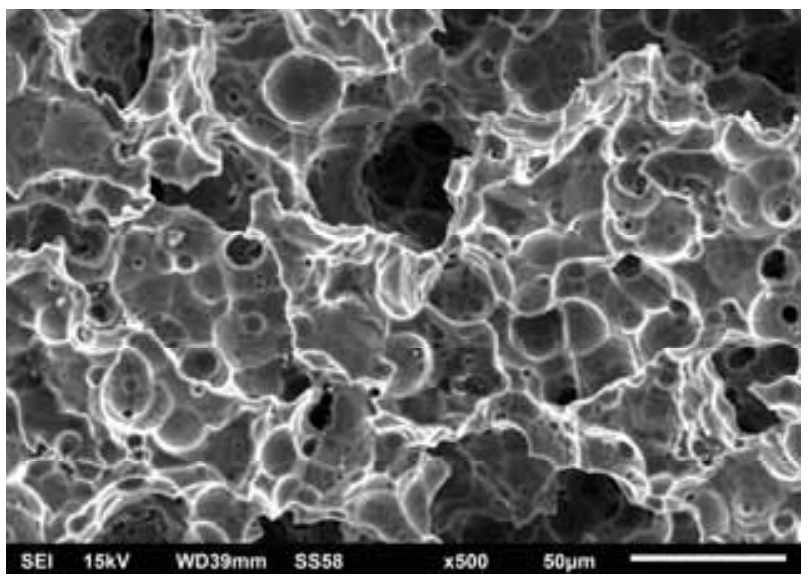

c)

Figure 10. Surface morphology of the weld joint after the NAMLT test: a) base metal; b) HAZ; c) WM.

\section{Exfoliation and pitting corrosion susceptibility}

Exfoliation and pitting corrosion susceptibility were estimated after a visual inspection according to the ASTM G66 standard. Fig.11 presents the surface appearance of the base metal and TIG welded specimen samples after the exfoliation corrosion test. In both specimens, the surface was etched, but without any pitting, pit blistering or a visible lifting of the surface. According to the ASTM G66, both samples passed the test with no appreciable attack. In addition, it is interesting to note that AlMg6Mn alloy is very susceptible to intergranular attack in $\mathrm{HNO}_{3}$, as evidenced by ASTM G67, but on the contrary, it satisfies the highest requirements regarding the exfoliation and pitting resistance, as concluded after the ASTM G66 procedure.

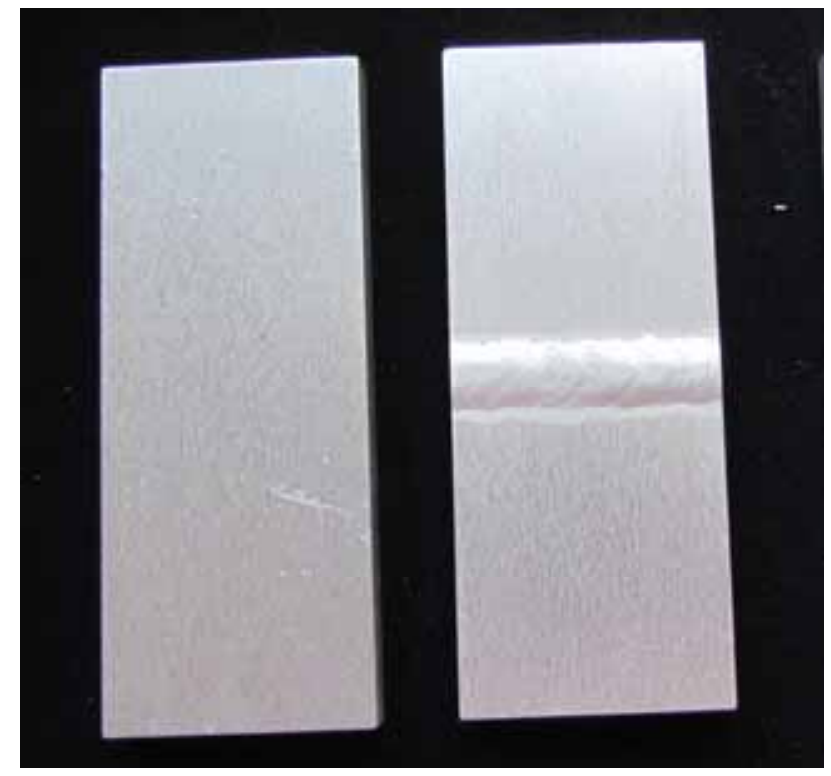

Figure 11. Base metal and TIG welded specimen of AlMg6Mn alloy after the exfoliation susceptibility test.

specimens have shown better IGC resistance than as-received specimens, since the mass loss in NAMLT test was between $15.45 \mathrm{mg} / \mathrm{mm}^{2}$ and $30.48 \mathrm{mg} / \mathrm{mm}^{2}$.

There is a clear correlation between the mass loss and surface morphology after exposure to nitric acid (NAMLT). In as-received specimens intergranular corrosion attack was observed, which is attributed to severe dissolution of $\beta$-phase 
along the grain boundaries. On the other hand, corrosion attack in the TIG welded specimens was not intergranular. The increase of corrosion resistant of TIG weld compared to as-received alloy is a result different of microstructure: lower content of $\mathrm{Mg}$ in the filler material (AlMg5), and thus, lower content and size of the second phase particles, cast microstructure of the weld metal, and absence of the phase at the grain boundary.

The contribution of particular zones of weld to increase corrosion resistance of the weld will be the subject of further investigation.

Exfoliation corrosion, determined by a visual inspection using the ASSET method, was not observed neither in base metal nor in TIG weld specimens.

\section{Literature}

[1] SANDERS,JR.,E.R., HOLLINSHEAD,P.A., SIMIELLI,E.A.: Industrial Development of Non-Heat Treatable Aluminum, Materials Forum, 2004, Vol.28, pp.53-64.

[2] GOOCH,A.W., BURKINS,M.S., SQUILLACIOTI,R.J.: Ballistic testing of commercial aluminum alloys and alternate processing techniques to increase the availability of aluminum armor, 23rd International symposium on ballistics, Spain, 2007.

[3] The Aluminium Automotive Manual, Design - Design with Aluminium, European Aluminium Association, 2011.

[4] ROMHANJI,E., POPOVIĆ,M.: Problems And Prospect of Al-Mg Alloys Application In Marine Constructions, Metallurgical \& Materials Engineering, 2006, Vol.12, No.4, pp.297-307.

[5] MONDOLFO,F.L.: Aluminium Alloys: Structure and Properties, Boston, Butterworths, 1976.

[6] BURGER,G., GUPTA,K.A., JEFFREZ,W.P., LLOYD,J.D.: Microstructural control of aluminium sheet used in automotive applications, Materials Characterization, 1995, 35, pp.23-29.

[7] TAN,L., ALLEN,R.T.: Effect of thermomechanical treatment on the corrosion of AA5083, Corrosion Science, 2010, 52, pp.548-554.

[8] CARROLL,C.M., GOUMA,I.P., DAEHN,S.G., MILLS,J.M.: Effects of minor Cu additions on a Zn-modified Al-5083 alloy, Materials Science and Engineering, 2001, A319-321, pp.425-428.

[9] ROMHANJI,E., POPOVIĆ,M., GLIŠIĆ,D., DODOK,R., JOVANOVIC,D.: Effect of annealing temperature on the formability of Al-Mg4.5-Cu0.5 alloy sheets, Journal of Materials Processing Technology, 2006, 177, pp.386-389.

[10] SEN,R., KAISER,S., MITRA,M.K., BANERJEE,M.K.: Plane strain fracture toughness of scandium doped Al-6Mg alloy, Journal of Alloys and Compounds, 2008, 457, pp. 135-143.

[11] ROMHANJI,E, POPOVIĆ,M., RADMILOVIĆ,V.: Room temperature deformation behaviour of AlMg6.5 alloy sheet, Zeitschrift fur Metallkunde, 1999, 90 (4), pp.305-310.

[12] TIMOSHENKO,Y B.: On the relation between the Luders deformation and grain boundary structure in aluminium alloy, Revue Phys Appl, 1990, 25, pp.1001-1004.

[13] RADOVIĆ,LJ., NIKAČEVIĆ,M.: Microstructure and properties of cold rolled and annealed Al-Mg alloys, Scientific Technical Review, ISSN 1820-0206, 2008, Vol.LVIII, No.2, pp.14-20.

[14] RADOVIĆ,LJ., NIKAČEVIĆ,M., JORDOVIĆ,B.: Deformation behaviour and microstructure evolution of AlMg6Mn alloy during shear spinning Trans, Nonferrous Met. Soc., China, 2012, 22, pp.991-1000.
[15] GAO,J., DAVID,J.Q.: Enhancement of the Stress Corrosion Sensitivity of AA5083 by Heat Treatment, Met Mat Trans A, 2011, Vol.42A, pp. 356-364,

[16] GOSWAMI,G. SPANOS,P.S., PAOA,R., HOLTZ,L.: Precipitation behavior of the phase in Al-5083 R. Materials Science and Engineering A 527, 2010, pp. 1089-1095,

[17] CHOI D.-H., AHN B.-WOOK, DAVID J. QUESNEL, SEUNG-BOO JUNG, Behavior of $\beta$-phase (Al3Mg2) in AA 5083 during friction stir welding, Intermetallics 35, 2013, pp.120-127.

[18] ZHU,Y.: Characterization of beta phase growth and experimental validation of long term thermal exposure sensitization of AA5xxx alloys, Master thesis, Department of Metallurgical Engineering The University of Utah, 2013.

[19] VARGEL,C.: Corrosion of Aluminium, Elsevier, 2004.

[20] GOSWAMI,R., SPANOS,G., PAO,P.S., HOLTZ,R.L.: Microstructural Evolution and Stress Corrosion Cracking Behavior of Al-5083, Met Mat Trans., 2011, Vol.42A, pp.348-355.

[21] JONES,R.H., BAER,D.R., DANIELSON,M.J., VETRANO,J.S.: Role of $\mathrm{Mg}$ in the Stress Corrosion Cracking of an Al-Mg Alloy, Metallurgical and Materials Transactions, A, 2001, Vol.32A, pp. 16991711.

[22] SEARLES,L.J., GOUMA,I.P., BUCHHEIT,R.G.: Stress Corrosion Cracking of Sensitized AA5083 (Al-4.5Mg-1.0Mn), Vol.32A, Metallurgical and Materials Transactions A, 2001, Vol.32A, pp. 285867.

[23] KHOSHNAW,F.M., GARDI,R.H.: Effect of aging time and temperature on exfoliation corrosion of aluminum alloys 2024-T3 and 7075-T6, Materials and Corrosion, 2007, 58, pp.345-347.

[24] ELTAI,E.O., MAHDI,E.: Electrochemical Corrosion and Mechanical properties of welded AA 6061 joined by TIG and MIG welding methods, Proc. Int. Conf. on Future Trends In Mechanical, Production and Automation Engineering- FTMPAE 2014.

[25] ZUCCHI,F., TRABANELLI,G., GRASSI,V.: Pitting and stress corrosion cracking resistance of friction stir welded AA5083, Materials and Corrosion, 2001, 52, pp.853-859

[26] MALARVIZHI,S., BALASUBRAMANIAN,V.: Effect of welding processes on AA2219 aluminium alloy joint properties, Trans. Nonferrous Met. Soc. China, 2011, 21, pp.962-973.

[27] Standard Test Method for Determining the Susceptibility to Intergranular Corrosion of 5XXX Series Aluminum Alloys by Mass Loss After Exposure to Nitric Acid (NAMLT Test).

[28] GUNSON,J.: Effect of sensitisation on the corrosion fatigue properties of AA5456-H116, Master thesis, Materials and Metallurgy University of Birmingham, 2010.

[29] OGUOCHA.A.N.I.: Effect of sensitization heat treatment on properties of Al-Mg alloy AA5083-H1 16, Mater Sci., 2008, 43, pp.4208-4214.

[30] MERDITH,S.G.: Friction stir processing for the reversal and mitigation of sensitisation and intergranular corrosion in aluminium alloy 5083-h321, PhD thesis, The School of Metallurgy and Materials College of Engineering and Physical Sciences The University of Birmingham, 2014.

[31] WINSLEY,R.: Effect of Heat Treatment and Friction Stir Welding on Corrosion of AA5083, PhD Thesis submitted to University of Birmingham, Department, of Metallurgy and Materials, UK.

[32] POPOVIC,M., ROMHANJI,E.: Characterization of microstructural changes in an Al-6.8 wt.\% Mg alloy by electrical resistivity measurements, Materials Science and Engineering A, 2008, 492, pp. $460-467$.

Received: 12.04.2016. Accepted: 21.06.2016.

\title{
Koroziono ponašanje AIMg6Mn legure zavarene TIG postupkom
}

\author{
Ispitan je uticaj TIG postupka zavarivanja na koroziono ponašanje i mehaničke karakteristike AIMg6Mn legure. Ploča \\ AIMg6Mn legure u polaznom, toplo valjanom stanju debljine $8 \mathrm{~mm}$ je zavarena TIG postupkom. Kao dodatni material je \\ korišćena žica S-AIMg5. Za ispitivanje mikrostrukture, mehaničkih karakteristika i otpornosti na koroziju su korišćene \\ metode optičke mikroskopije, skenirajuće elektronske mikroskopije, merenje tvrdoće, kao i NAMLT i ASSET test. \\ Pokazano je da je AIMg6Mn legura u polaznom stanju ima veću osetljivost na interkristalnu koroziju od TIG zavarenih \\ spojeva, dok su i polazno stanje i zavareni spojevi otporni na raslojavajuću koroziju.
}




\title{
Коррозионное поведение сплава Al-Mg-Mn полученного TIG-сваркой
}

\begin{abstract}
Здесь испытано влияние процесса TIG-сварки на коррозионное поведение и механические свойства сплава AlMg6Mn. Доска сплава AIMg6Mn в начальном, горячекатаном состоянии 8 мм толщиной приварена процессом TIG-сварки. В качестве дополнительного материала был использован провод S-AIMg5. Для того, чтобы исследовать микроструктуру, механические свойства и устойчивость к коррозии используются методы оптической микроскопии, сканирующей электронной микроскопии, измерения твёрдости и испытания ASSET и NAMLT. Здесь показано, что сплав AIMg6Мn в исходном состоянии имеет более высокую восприимчивость к межкристаллитной коррозии чем TIG-сварные соединения, в то время как и исходное состояние и сварные швы очень коррозиеустойчивы на расслаивание.
\end{abstract}

Ключевые слова: плавы, сплавы Al-Mg-Mn, сварка, TIG-сварка, сварной шов, коррозия, межкристаллитная коррозия, механические характеристики.

\section{Le comportement de corrosion de l'alliage AlMg6Mn soudé par la procédure TIG}

\begin{abstract}
L'influence du soudage TIG sur le comportement corrosif et les caractéristiques mécaniques de l'alliage AlMg6Mn a été examiné. Une plaque en alliage AIMg6Mn à l'état initial d'épaisseur de $8 \mathrm{~mm}$ roulée à chaud a été soudée au moyen de cette procédure. On a utilisé le fil S-AIMg5 comme le matériel supplémentaire. Pour examiner la microstructure, les caractéristiques mécaniques et la résistance à la corrosion on a utilisé les méthodes de la microscopie optique , la microscopie électronique scannant le mesurage de la dureté ainsi que le test NAMLT et ASSET. On a démontré que l'alliage AIMg6Mn à l'état initial possédait une sensibilité augmentée à la corrosion inter cristal par rapport aux soudures par TIG procédure tandis que l'état initial et les joints soudés étaient résistants à la corrosion exfoliée.
\end{abstract}

Mots clés: alliage, alliage Al-Mg-Mn, soudage, soudage TIG, joint soudé, corrosion, corrosion inter cristal, caractéristiques mécaniques. 